The correlation between wet and dry weight ... (Lisa Fajar Indriana)

\title{
THE CORRELATION BETWEEN WET AND DRY WEIGHT OF INTESTINE AND BODY WTHOUT INTESTINE OF SEA CUCUMBER (Holothuria scabra)
}

\author{
Lisa Fajar Indriana*)\# and Andreas Kunzmann ${ }^{* *}$ \\ *) Mataram Marine Bio Industry Technical Implementation Unit, Research Centre \\ for Oceanography, Indonesian Institute of Sciences \\ **) Leibniz Centre for Tropical Marine Ecology ZMT Bremen, Germany
}

(Received 5 December 2013; Accepted 6 May 2014)

\begin{abstract}
Holothuria scabra is a commercial tropical sea cucumber species, which has been exploited severely in recent years. This study was conducted at the Mataram Marine Bio Industry Technical Implementation Unit for 20 days aiming to determine the relationship between wet and dry weight of sea cucumbers with and without colon. Results of regression analysis between wet and dry weight show a significant positive correlation. The relationship between wet and dry weight without the colon is $y=$ $0.1685 x-0.2319\left(R^{2}=0.9236\right)$ whereas the wet and dry wet of the intestine is $y=$ $0.075 x+0033\left(R^{2}=0.791\right)$.
\end{abstract}

KEYWORDS: Lombok, Indonesia, colon weight, water content, food conversion, 'beche- de- mer', trepang, sandfish

\section{INTRODUCTION}

Sea cucumbers (Echinodermata: Holothuroidea) are widely consumed in Asia. This marine invertebrate is usually called "beche- demer" or "trepang" (Hu et al., 2010). There are 52 species commercially used as a source of food, most of them are tropical and sub- tropical species of the family Holothuriidae and Stichopodidae, including the genera Holothuria, Actinopyga, Bohadschia, and Stichopus (Choo, 2008).

Holothuria scabra is a tropical deposit- feeding sea cucumber found in the Indo- Pacific (Mercier et al., 1999) and is often called sandfish. It is a species with high commercial value (Conand, 1990). It is also the most popular among fisherman (Purwati, 2006) and one of the most widely distributed tropical sea cu- cumbers (Ramofafia et al., 2003). Sandfish is also cultured and has been bred extensively (Purcell et al., 2012).

Since $\mathrm{H}$. scabra has a commercial value, these cucumbers are studied extensively in both aquaculture and other fishery research. Some variables known about the sea cucumber include spatial distribution, daily activities of juveniles, and the reproductive cycle in the laboratory like spawning and larvae (Mercier et al., 1999); juvenile growth (Ramofafia et al., 1997); reproductive patterns and temporal changes (Muthiga et al., 2009); sediment patch selectivity (Uthicke \& Karez, 1999); growth and production (Paltzat et al., 2008). Further specific research requires initial and final dry body weight to obtain the specific growth rate (SGR), ingestion rate (IR), fecal production rate (FPR), food conversion efficiency (FCE) (Yuan et al.,

\# Corresponding author. Research Centre for Oceanography, Indonesian Institute of Sciences Jl. Teluk Kodek, Malaka, Pemenang, Lombok Utara, Nusa Tenggara Barat 83352 E-mail: lisaindriana23@gmail.com 
2006), and feed efficiency (FE) (Liu et al., 2010). In order to get the dry weight we had to put the animal to death, therefore it is extremely helpful to know the relationship between the dry and wet weight.

\section{OBJECTIVE}

To establish the correlation between wet weight and dry weight in sea cucumber $\mathrm{H}$. scabra for a wide size range, in order to prevent killing of individuals.

\section{MATERIAL AND METHODS}

The experiment was carried out from 5 to 24 November 2012. Twenty five sea cucumbers used in this study were collected from the coast of North Lombok, Indonesia. After 24 hours of fasting each sea cucumber was placed individually in a tank. Fifty percent water was exchanged everyday and aeration was provided continuously. Wet weight of each individual was taken daily. At the end of 20 days experiment, wet weight of intestine and wet weight of the body without intestine were taken and then dried in the oven at $60^{\circ} \mathrm{C}$ for 2 days. Then dry body and dry intestine were weighed. Water temperature, $\mathrm{pH}$, and salinity were monitored every 3 days. Finally a regression analysis was applied in order to establish the relationship of wet weight to dry weight.

\section{RESULTS AND DISCUSSION}

\section{Weight Change Over Time}

The average weight of sea cucumbers decreased during the 20 days $(-15.6656 \mathrm{~g} \pm$
$3.31 \mathrm{~g}$ ). The largest individual weight gain of one sea cucumber was $9.2 \mathrm{~g}$, the greatest loss - $56.93 \mathrm{~g}$ (Figure 1). It is assumed that the sea cucumber is not able to digest the food properly and the individuals studied obviously had developed stress. In nature, this type of sea cucumbers lives in muddy or sandy substrate in the seagrass meadow. Most of the commercial sea cucumbers are deposit feeders eating detritus, bacteria, and diatoms in the sediment at the seabed (Conand, 2006). However, this assumption requires further research. In holothurians, it is not easy to determine weight or length intervals and monitor how these factors develop over time. There are several factors, e.g. a variable water content and on a population level the unpredictability of recruitment and the scarcity of juveniles (Conand, 1990).

Water quality in this experiment was excellent and very close to ambient conditions, with an average temperature of $28.66^{\circ} \mathrm{C} \pm$ $0.14^{\circ} \mathrm{C}$, pH $7.56 \pm 0.02$, and salinity $34.29 \pm$ 0.29 .

\section{Correlation Between Wet Weight and Dry Weight}

Dry weight and wet weight of the sand sea cucumbers (both without the intestine) are connected in a linear equation. The equation obtained was $y=0.168 x-0.231$ with a correlation coefficient $\mathrm{R}^{2}=0.923$ (Figure 2 ).

For the wet- dry intestine relationship, there was a significant positive correlation reflected in the equation of $y=0.075 x+0.033$ with $a$ correlation coefficient $R^{2}=0.791$ (Figure 3 ).

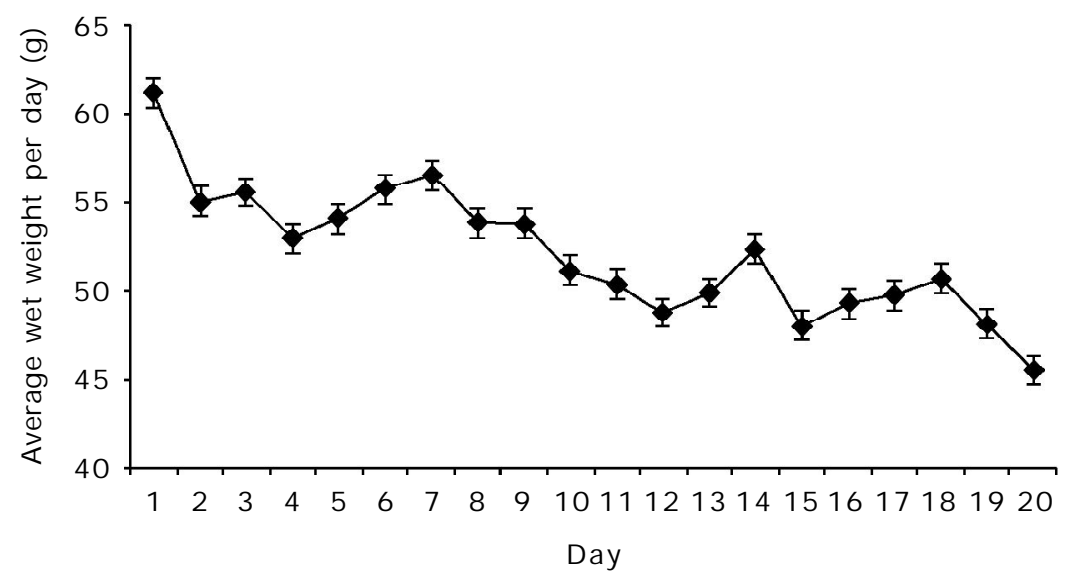

Figure 1. Average wet weight per day $(n=25)$ 
The correlation between wet and dry weight ... (Lisa Fajar Indriana)

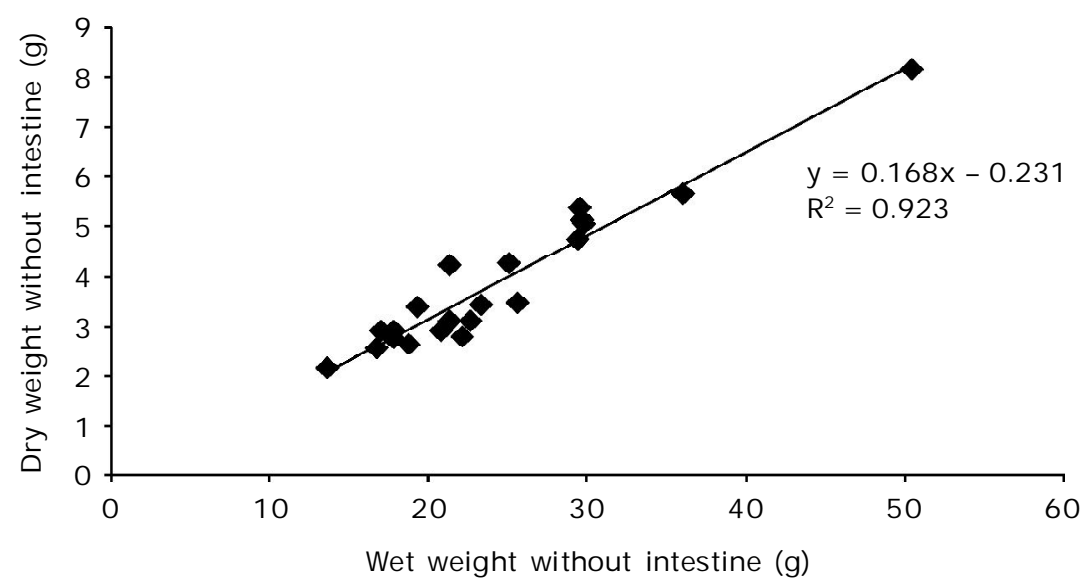

Figure 2. Relationship between dry and wet body weight without intestine in H. scabra $(n=21)$

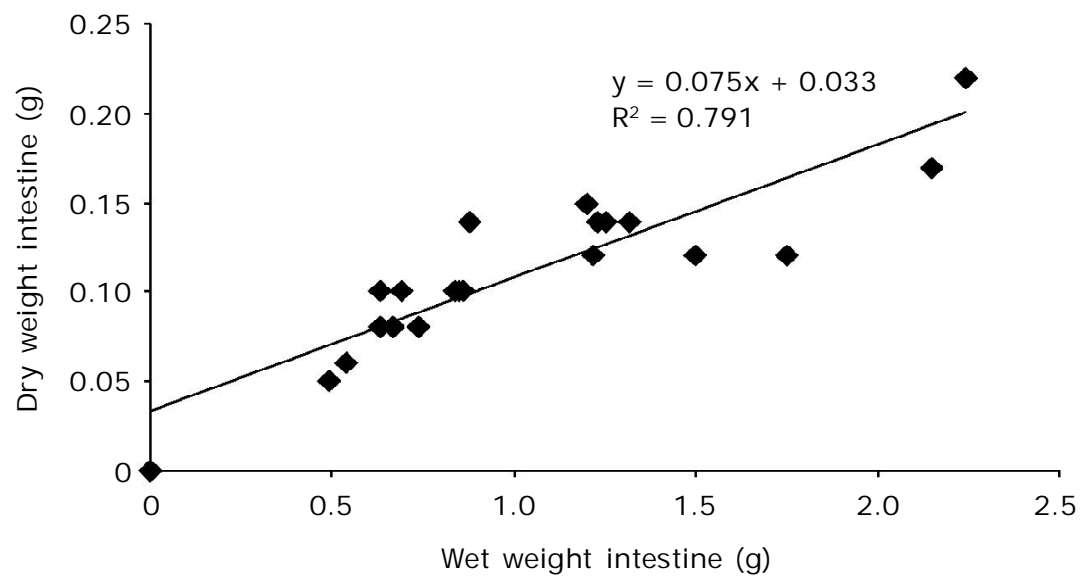

Figure 3. Wet- dry intestine relationship in H. scabra $(n=22)$

This equation can facilitate further research in estimating the dry weight of sea cucumbers without the need to kill the animals; it can also be used to estimate the water content in each individual. For this species it is now possible to just use the records of wet body weight data and with the help of the equations above, the respective dry weight data can be predicted. For future research we suggest to increase the size range for more maximum and minimum values in order to better represent a population so the equations obtained will be more accurate. Some studies are using the dry weight data of sea cucumbers for energy consumption (C), the energy discharged in the feces $(F)$, energy for growth or scope for growth (SFG) (Yuan et al., 2010), specific growth rate
(SGR) (Dong et al., 2006), specific growth rate in terms of energy (SGRe) (Yang et al., 2005); and ingestion rate (IR), fecal production rate (FPR) (Liu et al., 2009), but for these studies other species were used.

\section{ACKNOWLEDGEMENTS}

We would like to thank the Centre for Science and Technology of the Non- Aligned and Other Developing Countries (NAM S \& T Centre) as well as the Leibniz Center for Tropical Marine Ecology ZMT Bremen, Germany. We also thank Dr. Achim Meyer, Matthias Birkicht from ZMT, and the colleagues from LIPI who supported this research: Nurhalis Tarmin, Abdul Wahab, D. Ariesta Anggorowati, Hollanda Arif K. 


\section{REFERENCES}

Choo, P.S. 2008. Population status, fisheries and trade of sea cucumbers in Asia. In Toral- Granda, V., Lovatelli, A., \&Vasconcellos, M. (Eds.), Sea cucumbers. A global review of fisheries and trade. FAO Fisheries and Aquaculture Technical Paper. Rome, 516: 81-118.

Conand, C. 1990. The fishery resources of Pacific island countries Part 2. Holothurians. FAO Fisheries Technical Paper. Rome, 272(2): 143

Conand, C. 2006. Sea cucumber, biology, taxonomy, distribution and conservation status. In Bruckner, A.W. (Ed.), Proceedings of the CITES workshop on the conservation of sea cucumbers in the families Holothuriidae and Stichopodidae. NOAA Technical Memorandum NMFS- OPR- 34. USA, p. 33- 50.

Dong, Y., Dong, S., Tian, X., Wang, F., \& Zhang, M. 2006. Effects of diel temperature fluctuations on growth, oxygen consumption and proximate body composition in the sea cucumber Apostichopus japonicus Selenka. Aquaculture, 255: 514- 521.

Hu, C., Xu, Y., Wen, J., Zhang, L., Fan, S., \& Su, T. 2010. Larval development and juvenile growth of the sea cucumber Stichopus sp. (Curry fish). Aquaculture, 300: 73- 79.

Liu, Y., Dong, S., Tian, X., Wang, F., \& Gao, Q. 2009. Effects of dietary sea mud and yellow soil on growth and energy budget of the sea cucumber Apostichopus japonicus (Selenka). Aquaculture, 286: 266- 270.

Liu, Y., Dong, S., Tian, X., Wang, F., \& Gao, Q. 2010. Short communication: The effect of different macroalgae on the growth of sea cucumbers (Apostichopus japonicus Selenka). Aquaculture Research, 41: 881885.

Mercier, A., Battaglene, S.C., \&Hamel, J.F. 1999. Daily burrowing cycle and feeding activity of juvenile sea cucumbers Holothuria scabra in response to environmental factors. Journal of Experimental Marine Biology and Ecology, 239: 125- 156.

Muthiga, N.A., Kawaka, J.A., \& Ndirangu, S. 2009. The timing and reproductive output of the commercial sea cucumber Holothuria scabra on the Kenyan coast. Estuarine, Coastal and Shelf Science, 84: 353- 360.
Paltzat, D.L., Pearce, C.M., Barnes, P.A., \& McKinley, R.S. 2008. Growth and production of California sea cucumbers (Parastichopus californicus Stimpson) co-cultured with suspended Pacific oysters (Crassostrea gigas Thunberg). Aquaculture, 275: 124- 137.

Purcell, S.W., Hair, C.A., \& Mills, D.J. 2012. Sea cucumber culture, farming and sea ranching in the tropics: Progress, problems and opportunities. Aquaculture, 681: 368- 369.

Purwati, P. 2006. Souvenir from West Lombok, eastern Indonesia. SPC Beche-de-mer Information Bulletin, 23: 26- 28.

Ramofafia, C., Byrne, A.M., \& Battaglene, A.C.S. 2003. Reproduction of the commercial sea cucumber Holothuria scabra (Echinodermata: Holothuroidea) in the Solomon Islands. Marine Biology, 142: 281- 288.

Ramofafia, C., Foyle, T.P., \& Bell, J.D. 1997. Growth of juvenile Actinopyga mauritiana (Holothuroidea) in captivity. Aquaculture, 152: 119- 128.

Uthicke, S. \& Karez, R. 1999. Sediment patch selectivity in tropical sea cucumbers (Holothurioidea: Aspidochirotida) analysed with multiple choice experiments. Journal of Experimental Marine Biology and Ecology, 236: 69- 87.

Yang, H., Yuan, X., Zhou, Y., Mao, Y., Zhang, T., \& Liu, Y. 2005. Effects of body size and water temperature on food consumption and growth in the sea cucumber Apostichopus japonicus (Selenka) with special reference to aestivation. Aquaculture Research, 36: 1,085- 1,092.

Yuan, X., Yang, H., Zhou, Y., Mao, Y., Zhang, T., $\&$ Liu, Y. 2006. The influence of diets containing dried bivalve feces and/or powdered algae on growth and energy distribution in sea cucumber Apostichopus japonicus (Selenka) (Echinodermata: Holothuroidea). Aquaculture, 256: 457- 467.

Yuan, X., Yang, H., Wang, L., Zhou, Y., \& Gabr, H.R. 2010. Effects of salinity on energy budget in pond-cultured sea cucumber Apostichopus japonicus (Selenka) (Echinodermata: Holothuroidea). Aquaculture, 306: 348- 351. 